\title{
AGRONOMICAL CHARACTERS OF INTRODUCED NEW BLACKCURRANT CULTIVARS
}

\author{
Audrius Sasnauskas, Tadeušas Šikšnianas, Vidmantas Stanys, Pranas Viškelis, \\ Ramunè Bobinaitè, Marina Rubinskienè, and Česlovas Bobinas
}

Institute of Horticulture, Lithuanian Research Centre for Agriculture and Forestry,

Kauno 30, Babtai, Kaunas district, LT-54333, LITHUANIA

A.Sasnauskas@Isdi.It

Communicated by Edite Kaufmane

The blackcurrant cultivars 'Abanos', 'Ronix', 'Deea', 'Geo' (Romania), 'Almo' (Estonia), 'Narve Viking', 'Varde Viking' (Norway), 'Mikael' (Finland), and standard cultivar 'Ben Tirran' (Scotland) were tested at the Institute of Horticulture, Lithuanian Research Centre for Agriculture and Forestry in 2009-2012. Two-year-old bushes were planted in an orchard in 2009. Bush parameters (vigour and width, $m$ ), resistance to anthracnose (Pseudopeziza ribis) and leaf spot (Septoria ribis), berry weight (weight of 100 fruits), yield (kg/bush) and biochemical composition were determined. The study showed that 'Geo' was most resistant to fungal disease. Fruits of 'Abanos' and 'Almo' were the largest. Yield of cultivars 'Ronix', 'Ben Tirran' and 'Deea' were the highest. 'Abanos' and 'Geo' had the highest content of soluble solids, 'Ben Tirran' of titratable acid, 'Varde Viking' of anthocyanins and phenols, and 'Ronix' and 'Narve Viking'of ascorbic acid.

Key words: blackcurrant, Ribes, cultivar, yield, diseases, biochemical composition.

Blackcurrant (Ribes nigrum L.) is the most important bush fruit grown commercially in Lithuania, and is planted in a area of 2900 ha. The climate of Lithuania is suitable for blackcurrant production (Sasnauskas et al., 2012). Blackcurrant fruit is rich in many bioactive compounds. Buds and their essential oil extracts have become increasingly important (Dvaranauskaite et al., 2008; 2009). The main targets of Ribes breeding programmes are fruit yield and quality, resistance to pest and fungal diseases, suitability for processing and fresh market, and adaptability to local environmental conditions (Pluta and Zurawicz, 1993; Trajkovski et al., 2000; Brennan et al., 2008; Libek et al., 2008; Paprstein et al., 2012; Yareshchenko et al., 2012; Strautina et al., 2012). Since 1946, the breeding programme for blackcurrant has been carried out at the Institute of Horticulture, Lithuanian Research Centre for Agriculture and Forestry (IH-LRCAF). Seventeen new IH-LRCAF cultivars are included in the National List of Plant Varieties 2012 and recommended for commercial growing in Lithuania (Sasnauskas et al., 2012). There is still a strong need for new blackcurrant cultivars, because some European cultivars are not winter hardy enough and susceptible to fungal diseases, but they have good berry quality. On the other hand, investigations of new blackcurrant cultivars are important for cross-combinations.

The objective of this study was to evaluate agronomical characters of nine blackcurrant cultivars under the soil and weather conditions in Lithuania and to select among these for breeding purposes.

Plant material. One-year old bushes were planted at the IH-LRCAF in autumn 2009. Evaluation and characterisation of the cultivars was performed in 2011-2012. Romanian cultivars ('Abanos', 'Ronix', 'Deea', 'Geo'), Estonian ('Almo'), Norwegian ('Narve Viking', 'Varde Viking') and Finish ('Mikael') cultivars were evaluated against the standard cultivar 'Ben Tirran' (Scotland), which is included in the National List of Plant Varieties. The soil in the experimental plot was Epicalcari-Endohypogleic cambisol, clay loam. Agrochemical soil characteristics were: $\mathrm{pH} 7.0(\mathrm{KCl}$ extract), humus $2.3 \%, \mathrm{P}_{2} \mathrm{O}_{5} 290 \mathrm{mg} \mathrm{kg}^{-1}$, and $\mathrm{K}_{2} \mathrm{O} 180 \mathrm{mg}$ $\mathrm{kg}^{-1}$. During the study period, air temperature and precipitation were similar to the multiannual value, except that in 2012 more precipitation was observed at the period of ripening berries. Minimal air temperature in January 2012 dropped to $-29{ }^{\circ} \mathrm{C}$, but no symptoms of shoot damage were observed.

The experiment was established in a randomised block design in three replications of one plant each. Planting density was $3 \times 1 \mathrm{~m}$. The plants were not treated with pesticides and not irrigated. Growing, fertilisation, weed control, soil cultivation and treatment of blackcurrant cultivars were carried out according to recommendations of the Lithuanian Institute of Horticulture (Sasnauskas et al., 2002). 
Bush and fruit evaluation. The following agronomical characters were studied: bush height and width, m; yield $\left(\mathrm{kg} / \mathrm{bush}\right.$ and $\mathrm{tha}^{-1}$ ); weight of 100 fruits and the largest fruit, $\mathrm{g}$; and resistance to anthracnose (Pseudopeziza ribis Kleb.) and leaf spot (Septoria ribis Lib/Desm.) using a scale 0-5 (where $0-$ no disease symptoms detected on leaves, 5 - infected more than $75 \%$ of leaf area). The biochemical composition of fruits was analysed by the following methods: soluble solids by digital refractometer ATAGO, \%; titrable acidity by titration with $0.1 \mathrm{M} \mathrm{NaOH}, \%$; ascorbic acid by titration with 2.6-dichlorphenolindophenol sodium salt solution, $\mathrm{mg} 100 \mathrm{~g}^{-1}$ (Viskelis et al., 2010); anthocyanins spectrophotometrically at wavelength $\lambda 544 \mathrm{~nm}$, mg $100 \mathrm{~g}^{-1}$ (Speiciene et al., 2008); and phenols by photometric method using Folin-Ciocalteau reagent (Slinkard, Singleton, 1977). A sample of berries was taken at picking time (second decade of July) when ripe in $95 \%$ of a bush. Fungal disease symptoms were observed at maximal time of spread time in July - August.

The data were analyzed using ANOVA. The significance of differences between the evaluated cultivars was estimated using the LSD test at $P=0.05$.

Bush parameters. In the fourth year of growth the plant height of tested blackcurrant genotypes ranged from $0.92 \mathrm{~m}$ ('Mikael') to $1.46 \mathrm{~m}$ ('Geo') (Table 1). Bush width ranged from $0.88 \mathrm{~m}$ ('Mikael') to $1.88 \mathrm{~m}$ ('Geo'). Suitable cultivars for machine harvesting need upright and flexible branches (Kampuss and Strautina, 2000). According to the bush height and width ratio, 'Narve Viking', 'Varde Viking', 'Mikael' and 'Ben Tirran' were well adapted to machine harvesting.

Yield and fruit size. The average yields for the first year of cropping of the tested cultivars ranged from 0.14 to 0.78 $\mathrm{kg} / \mathrm{bush}$. The highest yields were obtained from cultivar 'Ronix', 'Deea' and 'Narve Viking' (Table 2). According to bush size in the second year of cropping all cultivars produced significantly higher yields. Highest summed yields were obtained from cultivars 'Ben Tirran', 'Ronix' and 'Deea', and the lowest from 'Mikael' and 'Geo'. 'Ronix'
Table 1

BUSH PARAMETERS OF BLACKCURRANT CULTIVARS (2012)

\begin{tabular}{lcc|c}
\hline \multicolumn{1}{c|}{ Cultivars } & $\begin{array}{c}\text { Bush height } \\
(\mathrm{m})\end{array}$ & $\begin{array}{c}\text { Bush width } \\
(\mathrm{m})\end{array}$ & $\begin{array}{c}\text { Bush height and } \\
\text { width ratio }\end{array}$ \\
\hline Ben Tirran & 0.96 & 0.97 & 1.03 \\
Abanos & 1.31 & 1.67 & 0.78 \\
Almo & 1.17 & 1.25 & 0.92 \\
Deea & 1.34 & 1.47 & 0.91 \\
Geo & 1.46 & 1.88 & 0.76 \\
Mikael & 0.92 & 0.88 & 1.05 \\
Narve Viking & 1.03 & 0.98 & 1.07 \\
Ronix & 1.42 & 1.84 & 0.77 \\
Varde Viking & 1.06 & 1.01 & 1.06 \\
LSD 05 & 0.13 & 0.24 & 0.21
\end{tabular}

produced the highest yield, followed by 'Ben Tirran' and 'Deea'.

Fruit size is the most important trait in the dessert type of blackcurrant cultivars. In 2011, cultivars 'Almo', 'Narve Viking' and 'Mikael' had the largest fruits, while 'Ben Tirran' produced the smallest fruits (Table 2). In the second year of cropping when there was high precipitation in the period of ripening berries, cultivar 'Abanos' had the largest fruits, while 'Narve Viking' and 'Varde Viking' had the smallest fruits. Abanos' and 'Almo' dominated according to weight of the largest fruit.

Field resistance to fungal diseases. Blackcurrant cultivars showed different levels of field resistance to the fungal diseases (Table 3). Cultivars 'Narve Viking' and 'Mikael' were the most susceptible to leaf spot (Septoria ribis Lib./Desm), similar to the standard cultivar 'Ben Tirran', while 'Geo' was the least susceptible to this disease. The plant infection of tested blackcurrant genotypes by anthracnose also varied: cultivars 'Geo' and 'Varde Viking' were the most resistant to this pathogen.

Biochemical composition. The biochemical composition of the fruits in 2012 is presented in Table 4. There was considerable variation between the cultivars. The highest content of soluble solids was found in fruits of cultivars 'Abanos'

Table 2

YIELD AND FRUIT WEIGHT OF BLACKCURRANT CULTIVARS

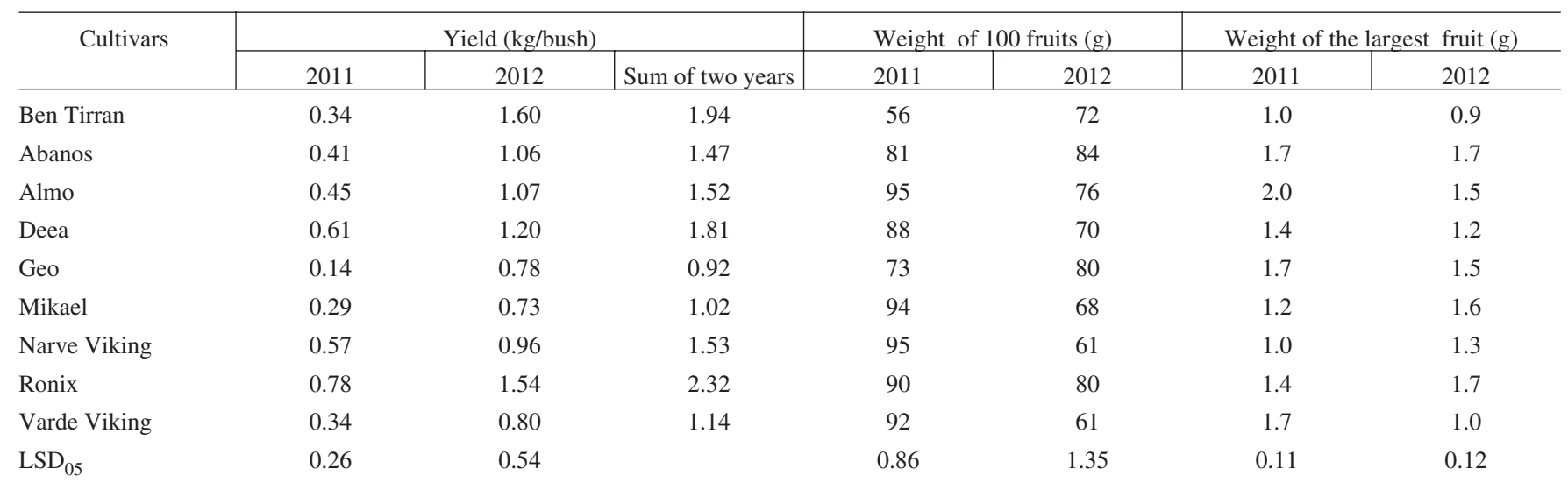


Table 3

RESISTANCE TO FUNGAL DISEASES OF BLACKCURRANT CULTIVARS, SCORES*

\begin{tabular}{|c|c|c|c|c|}
\hline \multirow[t]{2}{*}{ Cultivars } & \multicolumn{2}{|c|}{$\begin{array}{c}\text { Leaf spot } \\
\text { scores }\end{array}$} & \multicolumn{2}{|c|}{$\begin{array}{c}\text { Anthracnose } \\
\text { scores }\end{array}$} \\
\hline & 2011 & 2012 & 2011 & 2012 \\
\hline Ben Tirran & 1.7 & 0.5 & 2.5 & 1.8 \\
\hline Abanos & 1.0 & 0.7 & 1.8 & 0.7 \\
\hline Almo & 0.2 & 2.2 & 0.2 & 1.1 \\
\hline Deea & 1.5 & 1.1 & 1.2 & 0.8 \\
\hline Geo & 0.7 & 0.7 & 0.8 & 0.2 \\
\hline Mikael & 1.7 & 2.8 & 1.3 & 1.7 \\
\hline Narve Viking & 1.7 & 4.0 & 1.8 & 2.2 \\
\hline Ronix & 0.8 & 3.1 & 2.1 & 2.3 \\
\hline Varde Viking & 0.5 & 1.3 & 0.1 & 0.2 \\
\hline $\mathrm{LSD}_{05}$ & 0.95 & 0.64 & 0.71 & 0.83 \\
\hline
\end{tabular}

* Ranking scale 0-5 (where 0 - no disease symptoms detected on leaves, 5 - infected more than $75 \%$ of leaf area).

Table 4

BIOCHEMICAL COMPOSITION OF BLACKCURRANT CULTIVARS (2012)

\begin{tabular}{|c|c|c|c|c|c|}
\hline Cultivars & \begin{tabular}{|c|} 
Soluble \\
solids \\
$($ Brix, \% $)$
\end{tabular} & $\left|\begin{array}{c}\text { Titrable } \\
\text { acidity } \\
(\%)\end{array}\right|$ & 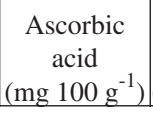 & 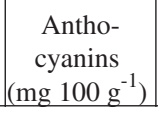 & $\begin{array}{c}\text { Phenols } \\
\left({\left.\mathrm{mg} 100 \mathrm{~g}^{-1}\right)}\right.\end{array}$ \\
\hline Ben Tirran & 20.8 & 3.33 & 229 & 381.2 & 1155.1 \\
\hline Abanos & 23.8 & 2.68 & 218 & 374.3 & 1100.0 \\
\hline Almo & 22.6 & 2.73 & 167 & 514.2 & 1089.3 \\
\hline Deea & 22.0 & 2.69 & 239 & 352.0 & 1054.2 \\
\hline Geo & 23.1 & 2.60 & 239 & 373.3 & 1098.1 \\
\hline Mikael & 21.0 & 2.53 & 149 & 336.0 & 925.2 \\
\hline Narve Viking & 20.5 & 2.55 & 243 & 461.1 & 1131.2 \\
\hline Ronix & 22.7 & 2.68 & 242 & 391.2 & 997.2 \\
\hline Varde Viking & 20.4 & 2.82 & 179 & 726.1 & 1151.1 \\
\hline $\mathrm{LSD}_{05}$ & 1.09 & 0.03 & 1.96 & 1.19 & 0.29 \\
\hline
\end{tabular}

and 'Geo', while titratable acidity was highest in fruits of 'Ben Tirran'. The content of ascorbic acid was highest in the fruits of 'Ronix' and 'Narve Viking'. Fruits of 'Varde Viking' and 'Almo' were distinguished by the highest amount of anthocyanins. Phenols content fluctuated from 925.2 to $1151.1 \mathrm{mg} 100 \mathrm{~g}^{-1}$. Fruits of 'Ben Tirran' and 'Varde Viking' accumulated the highest amount of phenols.

The size of bushes (height and width of plants) was variable and depended on genotype (Sasnauskas et al., 2012). Blackcurrant cultivars suitable for machine harvesting must be upright with flexible branches (Kampuss and Strautina, 2000; Kikas et al., 2012). This important morphological feature of plants is associated with the efficiency of mechanical harvesting and the degree of shoot damage by the harvester (Salamon, 1993). It was found that 'Narve Viking', 'Varde Viking', 'Mikael' and 'Ben Tirran' were very well adapted to machine harvesting.
The highest yield was obtained from cultivars 'Ronix', 'Deea' and standard cultivar 'Ben Tirran'. As in trials in Romania (Mladin et al., 1997), 'Abanos' and 'Almo' had the largest fruit. These cultivars were selected for large fruit size in Romania and Estonia (Mladin, 2001; Kask et al., 2010).

Resistance to fungal diseases is important for new blackcurrant cultivars. In our study, cultivar 'Geo' was the most resistant to fungal diseases (leaf spot and anthracnose). Mladin et al. (2012) also found this cultivar to be the most resistant to fungal diseases.

The biochemical content differed between cultivars. The cultivars 'Abanos' and 'Geo' had the highest content of soluble solids, while highest content of titratable acid was in fruits of 'Ben Tirran'. Ascorbic acid and different antioxidants in fruits are important factors in reducing several chronic diseases. The content of anthocyanins and phenols was highest in fruits of the Norwegian cultivar 'Varde Viking'. The highest ascorbic acid level was found in 'Ronix' and 'Narve Viking'.

Based on the results of bush parameters, yield and fruit size, field resistance to fungal diseases and biochemical composition, 'Ronix' from Romania as well as Norwegian cultivar 'Varde Viking' performed well among the tested blackcurrant cultivars. These can be recommended for used in breeding programmes.

This work was carried out within the framework of the long-term research program "Horticulture: agro-biological basics and technologies" implemented by the Lithuanian Research Centre for Agriculture and Forestry.

\section{REFERENCES}

Brennan, R., Stewart, D., Russell J. (2008). Developments and progress in Ribes breeding. Acta Hort., 777, 49-56.

Dvaranauskaite, A., Venskutonis, P. R., Raynaud, C., Talou, T., Viškelis, P., A. Sasnauskas, A. (2009). Variations in the essential oil composition in buds of six blackcurrant (Ribes nigrum L.) cultivars at various development phases. Food Chem., 114, 671-679.

Dvaranauskaite, A., Venskutonis, P.R., Raynaud, C., Talou, T., Viskelis, P., Dambrauskiene, E. (2008). Characterization of steam volatiles in the essential oil of black currant buds and the antioxidant properties of different bud extracts. J. Agric. Food Chem., 56 (9), 3279-3286.

Yareshchenko, A., Tereshchenko, Y., Pryimachuk, L., Todosyuk, E., Mazur, B. (2012). Ribes breeding programmes in Ukraine-recent achievements. Acta Hort., 946, 177-180.

Kampus, K., Strautina, S. (2000). Preliminary evaluation of black currant (Ribes spp.) genetic resources In: Proceedings of the International Conference. Fruit Production and Fruit Breeding, Tartu, 12-13 September, 2000 (pp. 168-172). Tartu.

Kask, K., Jänes, H., Libek, A., Arus, L., Kikas, A., Kaldmäe, H., Univer N., Univer T. (2010). New cultivars and future perspectives in professional fruit breeding in Estonia. Agron. Res., 8 (Special Issue III), 603-614.

Kikas, A., Kalmäe, H., Arus, L., Libek, A. V. (2012). Evaluation of blackcurrant cultivars for machine harvesting in Estonia. Acta Hort., 946, $143-147$.

Libek, A., Kikas, A., Kaldmäe, H., Arus, L. (2008). Blackcurrant breeding in Estonia. Acta Hort., 777, 77-80. 
Mladin, P., Mladin, G., Teodoresku, G. (1997). The genetic breeding of the blackcurrant in Romania. Bulletin de L'academie des sciences agricoles et forestieres, Gheorghe Ionescu Sisesti, Bucharest 24, 65-71.

Mladin, P. (2001). Achievements in black currant and raspberry breeding in Romania. Lucrasi stiintifice USAMV, Bucuresti, seria B, 44, 189-192.

Mladin, P., Mladin, G., Coman, M., Chitu, E., Chitu, V. (2012). Recent progress in berries breeding in Romania. Acta Hort., 926, 47-52.

Paprstein, F., Ludvikova, J., Sedlak, J., Cejka, B. (2012). New currant cultivars. Acta Hort., 946, 195-198.

Pluta, S., Zurawicz, E. (1993). Black currant (Ribes nigrum L.) breeding programme in Poland. Acta Hort., 352, 447-453.

Salamon, Z., (1993). Mechanical harvest of black currants and their sensitivity to damage. Acta Hort., 352, 109-112.

Sasnauskas, A., Siksnianas, T., Stanys, V., Bobinas, C. (2012). Evaluation of agronomical characters of blackcurrant cultivars and selections in Lithuania. Acta Hort., 946, 189-194.
Sasnauskas, A., Viškelis, P., Rašinskienè, A., Uselis, N. (2002). Blackcurrant. In: Intensive Growing Technologies of Small Fruits (pp. 137-190). Babtai: Lithuanian Institute of Horticulture (in Lithuanian).

Slinkard, K., Singleton, V. L. (1977). Total phenol analysis: Automation and comparison with manual methods. Amer. J. Enol. Vitic., 28, 49-55.

Speiciene, V., Leskauskaite, D., Viskelis, P., Rubinskiene, M. (2008). Rheological properties of currant purees and jams: Effect of composition and method of proceeding. J. Food, Agric. Envir., 6 (3-4), 162-166.

Strautina, S., Krasnova, I., Kalnina, I., Sasnauskas, A., Trajkovski, V., Tikhonova, O. (2012). Results of the common international breeding program for blackcurrant. Acta Hort., 926, 53-58.

Viskelis, P., Anisimovienè, N., Rubinskienè, M., Jankovska, E, Sasnauskas A. (2010). Physical properties, anthocyanins and antioxidant activity of blackcurrant berries of different maturities. J. Food, Agric. Envir. 8 (2), 159-162.

Trajkovski, V., Strautina, S., Sasnauskas, A. (2000). New perspective hybrids in breeding of black currants. Sodininkystè ir Daržininkystè, 19 (3)-2, $3-15$.

Received 7 December 2012

\section{JAUNO INTRODUCĒTO UPEN̦U ŠK̦IRN̦U AGRONOMISKAIS RAKSTUROJUMS}

Upeņu şķirņu pētījumi veikti Lietuvas Lauksaimniecības un Meža pētījumu centra Dārzkopības institūtā laikā no 2009 līdz 2012 . gadam. Pētîjumos iekḷautas šḳirnes 'Abanos', 'Ronix', 'Deea', 'Geo' (Rumānija), 'Almo' (Igaunija), 'Narve Viking', 'Varde Viking' (Norvēéija), 'Mikael' (Somija). Stādījums ierīkots 2009. gadā, izmantojot divgadīgus stādus. Pētîti krūmu parametri (augstums, platums, m) izturība pret ogulāju iedegām (Pseudopeziza ribis) un ogulāju sīkplankumainību (Septoria ribis), svērta ogu masa (100 ogu masa, g ), raža (kg/krūma) un analizēts biokīmiskais saturs. Pētījumu rezultāti rāda, ka izturīgākā pret sēṇu slimībām bija šḳirne 'Geo'. Lielākās ogas bija šḳirnēm 'Abanos' un 'Almo'. Augstākā ražība bija šķirnēm 'Ronix', 'Ben Tirran' un 'Deea', bet šķirnēm 'Abanos' and 'Geo' ogās bija augstākais škīstošās sausnas saturs. Škirnes 'Ben Tirran' ogas saturēja visvairāk titrējamās skābes , 'Varde Viking' antocianīnu un fenolu , 'Ronix’ un 'Narve Viking' — askorbīnskābi. 